Research Paper

\title{
Effect of Coriolus versicolor Mycelia Extract on Exercise Performance and Physical Fatigue in Mice
}

Chun-Sheng Ho ${ }^{1,2 *}$, Yu-Tang Tung ${ }^{3 *}$, Woon-Man Kung, ${ }^{4}$ Wen-Ching Huang5, Wing-Ki Leung5, Chi-Chang Huang ${ }^{2,3 凶}$ and Jyh-Horng $\mathrm{Wu}^{6 凶}$

1. Division of Physical Medicine and Rehabilitation, Lo-Hsu Foundation, Inc., Lotung Poh-Ai Hospital, Yilan 26546, Taiwan:

2. College of Exercise and Health Sciences, National Taiwan Sport University, Taoyuan 33301, Taiwan,

3. Graduate Institute of Metabolism and Obesity Sciences, Taipei Medical University, Taipei 11031, Taiwan;

4. Department of Neurosurgery, Lo-Hsu Foundation, Inc., Lotung Poh-Ai Hospital, Yilan 26546, Taiwan; Department of Exercise and Health Promotion,

College of Education, Chinese Culture University, Taipei 11114, Taiwan;

5. Graduate Institute of Athletics and Coaching Science, National Taiwan Sport University, Taoyuan 33301, Taiwan;

6. Department of Forestry, National Chung Hsing University, Taichung 40227, Taiwan.

* These authors contributed equally to this work.

$\square$ Corresponding authors: john5523@ntsu.edu.tw (C.-C. Huang); eric@nchu.edu.tw (J.-H. Wu).

(c) Ivyspring International Publisher. This is an open access article distributed under the terms of the Creative Commons Attribution (CC BY-NC) license (https://creativecommons.org/licenses/by-nc/4.0/). See http://ivyspring.com/terms for full terms and conditions.

Received: 2017.04.13; Accepted: 2017.07.24; Published: 2017.09.04

\begin{abstract}
In this study, Coriolus versicolor mycelia (CVM) was evaluated the ergogenic and anti-fatigue activities. Male ICR mice were divided into four groups ( $n=8 /$ group) to receive vehicle or CVM by oral gavage for 4 weeks at $0,615,1230$ or $3075 \mathrm{mg} / \mathrm{kg} / \mathrm{day}$, which were respectively designated the vehicle, CVM-1X, CVM-2X and CVM-5X groups. Forelimb grip strength, endurance swimming time, and levels of physical fatigue-associated parameters serum lactate, ammonia, glucose and creatine kinase (CK) after physical challenge were performed to evaluate exercise performance and anti-fatigue activity. Results revealed that the forelimb grip strength of mice in group CVM-1X, CVM-2X and CVM-5X were significantly increased by 1.20-, 1.18- and 1.23-fold, respectively, compared to the vehicle group. After the 15 minute swimming exercise, the levels of serum lactate of CVM-1X, CVM-2X and CVM-5X groups were significantly lower than the vehicle control group by $29 \%, 23 \%$ and $31 \%$, respectively. The levels of ammonia in CVM-1X, CVM-2X and CVM-5X groups were significantly lowered by $22 \%, 25 \%$ and $41 \%$, respectively, compared to the vehicle control group. In addition, the levels of serum CK in CVM-2X and CVM-5X groups were significantly lowered by $13 \%$ and $11 \%$, respectively, compared to the vehicle control group. Accordingly, the supplementation with CVM has beneficial effects on performance improvement and anti-fatigue activity, and thus has great potential as a source for natural health products.
\end{abstract}

Key words: Coriolus versicolor, mycelia, polysaccharopeptide, anti-fatigue, exercise performance.

\section{Introduction}

Fatigue is a term used to define a feeling of exhaustion, tiredness, weariness or lack of energy. Long-term physical fatigue leads to aging, depression, human immunodeficiency virus (HIV) infection, cancers, multiple sclerosis and Parkinson's disease [1]. Up to date, there were few pharmacological therapies for the treatment of fatigue [2]. Many researchers were interested in using plants to treat some clinical disorders. Now, researchers have turned to explore a wide variety of traditional herbal plants to decrease fatigue, accelerate the elimination of fatigue-related metabolites as well as improve athletic ability [3]

The mushroom Coriolus versicolor is a macrofungi belonging to the Basidiomycetes family and has been used in traditional Chinese medicine to treat various conditions, including various types of cancers, chronic hepatitis, as well as infections of the upper respiratory, urinary, digestive tracts and immunodeficient related diseases [4]. Previous studies have found that the crude extract of $C$. 
versicolor clearly has an extremely broad range of physiological effects which is related to the active components of polysaccharopeptides (PSP) [5, 6]. Studies showed that PSP have immunopotentiation by inducing production of interleukin 6 (IL-6), interferon (IFN), immunoglobulin G (IgG), macrophages and T-lymphocytes; counter immunosuppressive effects of chemotherapy, radiotherapy and blood transfusion; antagonize immunosuppression induced by tumors; inhibit proliferation of various cancers by inducing production of superoxide dismutase (SOD), glutathione peroxidase (GPx) and general immune enhancement; improve appetite and liver function; calm the central nervous system; and enhance pain threshold [6]. In addition, numerous researches have revealed that some polysaccharides extracted from traditional Chinese medicine herb have anti-fatigue activity [7-12]. Therefore, C. versicolor may be good candidates for further development as clinically used an anti-fatigue herbal supplement. However, to the best of our knowledge there is no prior report on the anti-fatigue activities of $C$. versicolor mycelia. In this study, we evaluated the anti-fatigue properties of $C$. versicolor mycelia by forelimb grip strength, endurance swimming time and levels of physical fatigue-associated parameters serum lactate, ammonia, glucose and creatine kinase (CK) after physical challenge.

\section{Methods}

\section{Materials}

A commercially available supplement, C. versicolor mycelia (CVM), was provided by GeneFerm Biotechnology (Taiwan) and employed as dietary treatment. The extraction of CVM has followed the method of the GeneFerm Biotechnology, and it contained $27.7 \%$ polysaccharide krestin (PSK).

\section{Animals and treatment}

Male ICR mice (4 weeks old; 20-25 g) were purchased from BioLASCO (A Charles River Licensee Corp., Yi-Lan, Taiwan). The experimental animals were given 1 week to acclimatize to the environment and diet. All animals were fed a chow diet (No. 5001; PMI Nutrition International, Brentwood, MO, USA) and distilled water ad libitum, and maintained at a regular cycle (12-h light/dark) at room temperature $\left(24 \pm 2^{\circ} \mathrm{C}\right)$ and $60-70 \%$ humidity. The bedding was changed and cleaned twice per week. All animal experimental protocols were approved by the Institutional Animal Care and Use Committee (IACUC) of National Taiwan Sport University, and the study conformed to the guidelines of the protocol
IACUC-10401 approved by the IACUC ethics committee.

32 mice were randomly assigned to 4 groups ( 8 mice/group). The oral gavage treatment with CVM once a day for 28 consecutive days: CVM at $615 \mathrm{mg} / \mathrm{kg}$ mouse/day (CVM-1X), $1230 \mathrm{mg} / \mathrm{kg}$ mouse/day (CVM-2X) and $3075 \mathrm{mg} / \mathrm{kg}$ mouse/day (CVM-5X). The vehicle control group received the same volume of distilled water equivalent to body weight. The food intake was monitored daily, and body weight was recorded weekly. At the end of the experiment, the mice were sacrificed. Serum was collected by centrifugation at $1,500 \mathrm{~g}, 4^{\circ} \mathrm{C}$ for $10 \mathrm{~min}$. The muscle, liver, kidney, EFP, heart, BAT and lung were collected and weighed. All of the samples were snap-frozen and stored at $-80^{\circ} \mathrm{C}$ until further analysis.

\section{Forelimb grip strength}

A low-force testing system (Model-RX-5, Aikoh Engineering, Nagoya, Japan) was used to measure forelimb absolute grip strength as we previously described [3] and maximal force (grams) was recorded. The force transducer equipped with a metal bar ( $2 \mathrm{~mm}$ in diameter and $7.5 \mathrm{~cm}$ in length) was used to measure the amount of tensile force from each mouse. We grasped the mouse at the base of the tail and lowered it vertically toward the bar. The mouse was pulled slightly backwards by the tail while the 2 paws (forelimbs) grasped the bar, which triggered a "counter pull". This grip strength meter recorded the grasping force in grams. Before CVM administration, all mice were trained to perform this procedure for 3 days. The 4 groups (Vehicle control, CVM-1X, CVM-2X and CVM-5X groups) did not differ in performing the activity. Grip strength was measured $1 \mathrm{~h}$ after the last treatment administration. The maximal force (grams) exerted by the mouse counter pull was used as forelimb grip strength.

\section{Exhaustive swimming test}

The mice were placed individually in a columnar swimming pool $(65 \mathrm{~cm}$ and radius of $20 \mathrm{~cm})$ with 40 $\mathrm{cm}$ water depth maintained at $24 \pm 1^{\circ} \mathrm{C}$. A weight equivalent to $5 \%$ of body weight was attached to the root of the tail and the swimming times were recorded from beginning to exhaustion for each mouse in groups. Exhaustion was determined by observing failure to swim and the swimming period was regarded as the time spent by the mouse floating in the water, struggling and making necessary movements until strength exhaustion and drowning. When the mice were unable to remain on the water surface, the mice were assessed. The swimming time from beginning to exhaustion was used to evaluate the endurance performance. 


\section{Fatigue-associated biochemical indices}

After the oral gavage treatment with CVM once a day for 28 consecutive days, mice underwent a 15-min swimming test without weight loading to evaluate fatigue-associated biochemical variables as in our previous studies $[3,13,14]$. Blood samples were immediately collected after the swimming exercise. Serum was collected by centrifugation, and lactate, ammonia, CK and glucose levels were determined by use of an auto-analyzer (Hitachi 7060, Hitachi, Tokyo).

\section{Blood biochemical assessments}

At the end of the experiments, all mice were sacrificed by $95 \% \mathrm{CO}_{2}$ asphyxiation, and blood was withdrawn by cardiac puncture after an 8-h fast. Serum was collected by centrifugation, and levels of $\mathrm{CK}$, glucose, lactate dehydrogenase (LDH), total cholesterol (T-Chol), triacylglycerol (TG), albumin (ALB), alkaline phosphatase (ALP), alanine aminotransferase (ALT), aspartate aminotransferase (AST), total protein (TP), blood urine nitrogen (BUN), creatinine (CREA) and uric acid (UA) were assessed by use of an auto-analyzer (Hitachi 7060).

\section{Pathological histology of tissues}

Liver, muscle, heart, kidney and lung tissues were removed at the end of the experiment, and fixed in $10 \%$ neutral buffered formalin for $24 \mathrm{~h}$ before being processed for histopathologic analysis as we previously described [15]. Tissues were embedded in paraffin and cut into $4-\mu \mathrm{m}$ thick slices for morphological and pathological evaluation, then stained with hematoxylin and eosin (H\&E) and examined by use of a light microscope equipped with a CCD camera (BX-51, Olympus, Tokyo).

\section{Statistical analyses}

All results were expressed as mean $\pm \operatorname{SEM}(n=8)$. The significance of difference was calculated by one-way ANOVA with Duncan's post test, and values $<0.05$ were considered to be significant. Pearson correlation for dose-dependent effect was used for all data comparisons and statistical analyses were conducted using the SPSS 19.0.

\section{Results and Discussion}

\section{Effect of 4-week CVM on body weight, food intake, water intake and tissue changes}

The results of body weight, food intake, water intake and tissue changes were shown in Table 1 . The one-way ANOVA results indicated that there were no significant differences in the body weight, food intake, water intake, muscle mass, liver mass, kidney mass, epididymal fat pad (EFP) mass, heart mass, brown adipose tissue (BAT) mass and lung mass of the mice in CVM-1X, CVM-2X and CVM-5X groups, in comparison with the vehicle control group. Similarly, results obtained by Tan et al. [12] also found orally administered polysaccharides from Radix Rehmanniae Preparata, the anti-fatigue product, at doses of 50, 100 and $200 \mathrm{mg} / \mathrm{kg}$ for 28 days had no significant effect on the body weight.

Table 1. Effect of 4-week CVM on body weight and tissue changes in mice

\begin{tabular}{|c|c|c|c|c|}
\hline Characteristic & Vehicle & CVM-1X & CVM-2X & CVM-5X \\
\hline Initial BW (g) & $24.7 \pm 0.2^{\mathrm{a}}$ & $24.6 \pm 0.2^{\mathrm{a}}$ & $24.8 \pm 0.3^{\mathrm{a}}$ & $24.4 \pm 0.2^{\mathrm{a}}$ \\
\hline Final BW (g) & $37.1 \pm 0.8^{a}$ & $37.1 \pm 0.6^{a}$ & $37.1 \pm 0.5^{\mathrm{a}}$ & $37.0 \pm 0.8^{\mathrm{a}}$ \\
\hline Food intake (g/day) & $6.8 \pm 0.1^{\mathrm{a}}$ & $6.5 \pm 0.2^{\mathrm{a}}$ & $6.8 \pm 0.1^{\mathrm{a}}$ & $6.8 \pm 0.2^{a}$ \\
\hline Water intake (mL/day) & $8.2 \pm 0.1^{\mathrm{a}}$ & $8.1 \pm 0.2^{a}$ & $8.2 \pm 0.2^{\mathrm{a}}$ & $8.4 \pm 0.39 a$ \\
\hline Muscle (g) & $0.35 \pm 0.01^{\mathrm{a}}$ & $0.37 \pm 0.01 \mathrm{a}$ & $0.37 \pm 0.01^{a}$ & $0.36 \pm 0.01^{\mathrm{a}}$ \\
\hline Liver (g) & $2.13 \pm 0.06^{\mathrm{a}}$ & $2.13 \pm 0.05^{a}$ & $2.12 \pm 0.03^{a}$ & $2.13 \pm 0.05^{\mathrm{a}}$ \\
\hline Kidney (g) & $0.61 \pm 0.03 \mathrm{a}$ & $0.61 \pm 0.02^{\mathrm{a}}$ & $0.63 \pm 0.02^{a}$ & $0.63 \pm 0.03 \mathrm{a}$ \\
\hline $\mathrm{EFP}(\mathrm{g})$ & $0.46 \pm 0.04^{\mathrm{a}}$ & $0.41 \pm 0.03 \mathrm{a}$ & $0.42 \pm 0.04 \mathrm{a}$ & $0.40 \pm 0.03 \mathrm{a}$ \\
\hline Heart (g) & $0.21 \pm 0.01^{\mathrm{a}}$ & $0.21 \pm 0.01^{a}$ & $0.21 \pm 0.01^{\mathrm{a}}$ & $0.21 \pm 0.01^{a}$ \\
\hline BAT (g) & $0.10 \pm 0.01^{\mathrm{a}}$ & $0.10 \pm 0.00^{a}$ & $0.10 \pm 0.01^{\mathrm{a}}$ & $0.11 \pm 0.01^{a}$ \\
\hline Lung (g) & $0.38 \pm 0.01^{\mathrm{a}}$ & $0.39 \pm 0.02^{a}$ & $0.38 \pm 0.02^{\mathrm{a}}$ & $0.39 \pm 0.02^{\mathrm{a}}$ \\
\hline $\begin{array}{l}\text { Relative muscle weight } \\
(\%)\end{array}$ & $0.97 \pm 0.02^{a}$ & $1.02 \pm 0.02^{a}$ & $1.03 \pm 0.02^{a}$ & $1.03 \pm 0.03 \mathrm{a}$ \\
\hline Relative liver weight (\%) & $5.89 \pm 0.09 \mathrm{a}$ & $5.77 \pm 0.08^{a}$ & $5.77 \pm 0.10^{a}$ & $5.79 \pm 0.10^{a}$ \\
\hline $\begin{array}{l}\text { Relative kidney weight } \\
(\%)\end{array}$ & $1.69 \pm 0.06^{\mathrm{a}}$ & $1.67 \pm 0.04^{a}$ & $1.69 \pm 0.03 a$ & $1.67 \pm 0.06^{a}$ \\
\hline Relative EFP weight (\%) & $1.15 \pm 0.08^{\mathrm{a}}$ & $1.13 \pm 0.07 \mathrm{a}$ & $1.15 \pm 0.09 a$ & $1.17 \pm 0.08^{a}$ \\
\hline Relative heart weight (\%) & $0.58 \pm 0.03^{\mathrm{a}}$ & $0.59 \pm 0.02^{\mathrm{a}}$ & $0.57 \pm 0.04^{\mathrm{a}}$ & $0.58 \pm 0.03^{a}$ \\
\hline Relative BAT weight (\%) & $0.28 \pm 0.01^{\mathrm{a}}$ & $0.29 \pm 0.01^{a}$ & $0.28 \pm 0.02^{\mathrm{a}}$ & $0.30 \pm 0.01^{\mathrm{a}}$ \\
\hline Relative lung weight (\%) & $1.05 \pm 0.03 \mathrm{a}$ & $1.07 \pm 0.03 \mathrm{a}$ & $1.09 \pm 0.03 \mathrm{a}$ & $1.09 \pm 0.06^{\mathrm{a}}$ \\
\hline
\end{tabular}

\section{Effect of 4-week CVM on forelimb grip strength}

The grip strength was higher with CVM-1X $(148 \pm 5 \mathrm{~g}), \mathrm{CVM}-2 \mathrm{X}(146 \pm 5 \mathrm{~g})$ and CVM-5X (152 $\pm 5 \mathrm{~g})$ than vehicle alone $(124 \pm 7 \mathrm{~g})(\mathrm{p}<0.05)$. Therefore, CVM-1X, CVM-2X and CVM-5X significantly increased relative absolute grip strength by 1.20-, 1.18and 1.23-fold, respectively, as compared with vehicle alone (Fig. 1A). Similarly, results obtained by Huang et al. [3] found that Antrodia camphorata treatments increased grip strength that improved physical fatigue and exercise performance in mice. The grip strength of mice in the vehicle, 50 and $200 \mathrm{mg} / \mathrm{kg}$ ethanolic extract of $A$. camphorata fruiting body $\mathrm{mg} / \mathrm{kg}$ was $125 \pm 5,142 \pm 1$ and $142 \pm 4 \mathrm{~g}$, respectively [3]. The present study revealed that CVM have a greater effect on grip strength than A. camphorate [3].

\section{Effect of 4-week CVM on an exhaustive swimming test}

Fatigue is one of the most frequent physiological 
responses. The level of physiological fatigue is determined by the energy metabolism of muscle activity [16] and the improvement of exercise endurance is the vital index in assessing anti-fatigue activity [16]. Anti-fatigue effect has been directly confirmed by improving exercise tolerance. An exhaustive swimming test is a proper experimental exercise model to assess anti-fatigue [17]. The swimming time represents the degree of fatigue [18]. The anti-fatigue activity of CVM in the present study is measured by an exhaustive swimming test, as shown in Fig. 1B. These results showed that the exhaustion time of the CVM-1X mice was $11.0 \mathrm{~min}$ ( $80 \%$ greater than that of the vehicle control group); the exhaustion time of the CVM-2X mice was $9.1 \mathrm{~min}$ (49\% greater than that of the vehicle control group); the exhaustion time of the CVM-5X mice was $9.4 \mathrm{~min}$ ( $53 \%$ greater than that of the vehicle control group). The result indicates that CVM treatments slightly prolonged the swimming time of the mice, but this increase is not statistically significant.

(A)

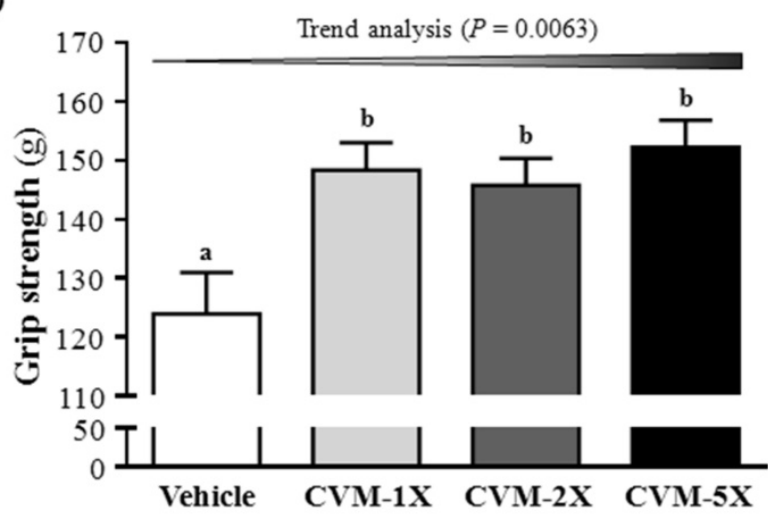

(B)

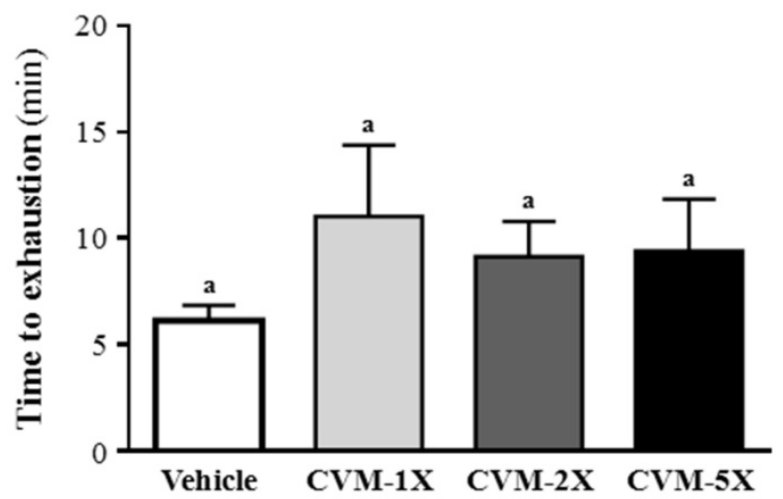

Figure 1. Effect of 4-week CVM on (A) forelimb grip strength and (B) endurance swimming performance in mice. Mice were pretreated with vehicle, CVM-1X, CVM-2X and CVM-5X for 28 days. Vehicle; vehicle control, CVM-1X; $615 \mathrm{mg} / \mathrm{kg} /$ day of CVM, CVM-2X; $1230 \mathrm{mg} / \mathrm{kg} /$ day of CVM, CVM-5X; 3075 $\mathrm{mg} / \mathrm{kg} /$ day of CVM. Data are mean \pm SEM ( $n=8 \mathrm{mice} /$ group). Different letters (a, b) indicated significant difference at $\mathrm{p}<0.05$ by one-way ANOVA.
In recent years, many PSP and PSK, which were isolated from different strains of $C$. versicolor, possessed the important medicinal value [19]. The previous studies demonstrated an anti-fatigue activity of polysaccharides in the forced swim test [20,21]. Similarly, results obtained by Tan et al. [12] reported that the exhaustive swimming time in 50, 100 and 200 $\mathrm{mg} / \mathrm{kg}$ of polysaccharides from Radix Rehmanniae Preparata were $406.6 \mathrm{~s}$ (6.8 min), $485.7 \mathrm{~s}$ ( $8.1 \mathrm{~min})$ and $596.6 \mathrm{~s}$ (9.9 $\mathrm{min})$, respectively, that indicated the increased ratio of exhausting swimming time of each treatment group were $10.07 \%, 31.48 \%$ and $61.51 \%$, respectively, compared with the vehicle control group. Thus, CVM has an excellent anti-fatigue activity that maybe due that CVM contains a wide variety of PSP and PSK. Thus, PSP and PSK of $C$. versicolor may be good candidates for further development as clinically used anti-fatigue drugs.

\section{Effect of 4-week CVM on lactate, ammonia, CK and glucose after a 15-min swimming test}

Blood lactate is the glycolysis product of carbohydrate under an anaerobic glycolysis, and blood lactate is a product of anaerobic glycolysis which supplies most energy source for high-intense exercise in a short time [22]. The increased lactate level further reduces $\mathrm{pH}$ value muscle tissue and blood, which could induce various adverse effects of various biochemical and physiological effects [3]. Therefore, the blood lactate is an important blood biochemical parameter and linked to fatigue [23]. After swimming, the level of blood lactate of CVM-1X, CVM-2X and CVM-5X groups were significantly lower $29 \%, 23 \%$ and $31 \%$, respectively, than that of the vehicle control group $(\mathrm{p}<0.05)$ (Fig. $2 \mathrm{~A})$. Similarly, results obtained by Jin and Wei [24] also found that, after swimming, the level of blood lactate in 60, 120 and $240 \mathrm{mg} / \mathrm{kg}$ tartary buckwheat extracts, an anti-fatigue supplementation, was lower $26.77 \%$, $36.58 \%$ and $41.89 \%$, respectively, than that of the vehicle control group. These results hinted that a diet supplementation of CVM can effectively lower the blood lactate produced after swimming and postpone the appearance of fatigue.

Ammonia, the metabolite of protein and amino acid, was related to fatigue [25]. The increase in ammonia during exercise can be controlled by the use of amino acids or carbohydrates, which interfere with ammonia metabolism [26]. The increase in ammonia level has a connection with both peripheral and central fatigue during exercise [3]. Therefore, the blood ammonia level related to fatigue is an important biochemical index. After treatment with CVM or vehicle to mice for 28 days, serum ammonia levels were notably lower with CVM-1X (105 \pm 5 
$\mathrm{mg} / \mathrm{dL} ; 22 \%$ lower than that of the vehicle control group), CVM-2X (101 $\pm 3 \mathrm{mg} / \mathrm{dL} ; 26 \%$ lower than that of the vehicle control group) and CVM-5X (80 \pm 3 $\mathrm{mg} / \mathrm{dL} ; 41 \%$ lower than that of the vehicle control group) than vehicle treatment $(135 \pm 7 \mathrm{mg} / \mathrm{dL})$ after the swimming test (Fig. 2B). And it significantly ameliorated dose-dependently with CVM treatment $(p<0.0001)$. Therefore, CVM should enhance ammonia elimination. Similarly, results obtained by Huang et al. [3] showed that plasma ammonia levels in the vehicle, $50 \mathrm{mg} / \mathrm{kg}$ and $200 \mathrm{mg} / \mathrm{kg}$ ethanolic extract of $A$. camphorata fruiting body were significantly lower, by $35 \%$ and $41 \%$, respectively, compared to vehicle treatment.

High-intensity exercise could cause physical or chemical tissue damage, and then lead to sarcomeric damage and muscular cell necrosis [27]. The muscle cells release $\mathrm{CK}$ into the blood indicating that muscle damage has occurred or is occurring. Clinically, CK is known to serve as an accurate indicator of muscle damage. As shown in Fig. 2C, the serum CK level of CVM-1X (106 $\pm 8 \mathrm{U} / \mathrm{L})$, CVM-2X $(160 \pm 18 \mathrm{U} / \mathrm{L})$ and CVM-5X (139 $\pm 6 \quad \mathrm{U} / \mathrm{L})$ groups was significantly decreased compared to the vehicle control $(400 \pm 74$ $\mathrm{U} / \mathrm{L})(\mathrm{p}<0.05)$. Similarly, results obtained by Huang et al. [3] showed that plasma CK activity in the vehicle, $50 \mathrm{mg} / \mathrm{kg}$ and $200 \mathrm{mg} / \mathrm{kg}$ ethanolic extract of $A$. camphorata fruiting body groups was significantly lower, by $41 \%$ and $54 \%$, respectively, than the vehicle treatment.

As shown in Fig. 2D, the blood glucose level of CVM-1X, CVM-2X and CVM-5X groups was significantly decreased than that of the vehicle control group ( $\mathrm{p}<0.05) ; 7 \%, 13 \%$ and $11 \%$ lower, respectively. Thus, we suggested that CVM may promote the glucose utilization to peripheral tissues and has a glucose lowering action.

\section{Effect of 4-week CVM on biochemical assessments of energy metabolism}

As compared with the vehicle control mice, the blood CK level of CVM-1X, CVM-2X and CVM-5X groups was significantly decreased compared to the vehicle control group ( $p<0.05) ; 35 \%, 25 \%$ and $35 \%$ lower, respectively. Accordingly, CVM dose-dependently reduced CK level as compared with the vehicle control mice $(P=0.0353)$ (Table 2$)$. In this study, CVM treatment reduced the blood CK levels both at rest and post-exercise.

(B)

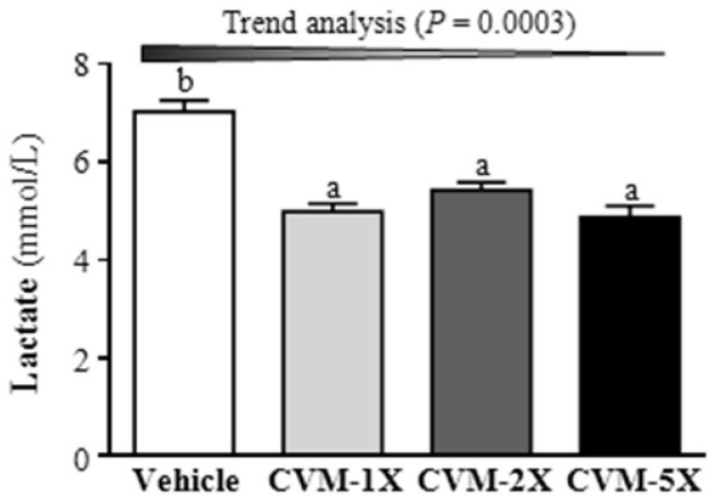

(C)

(D)
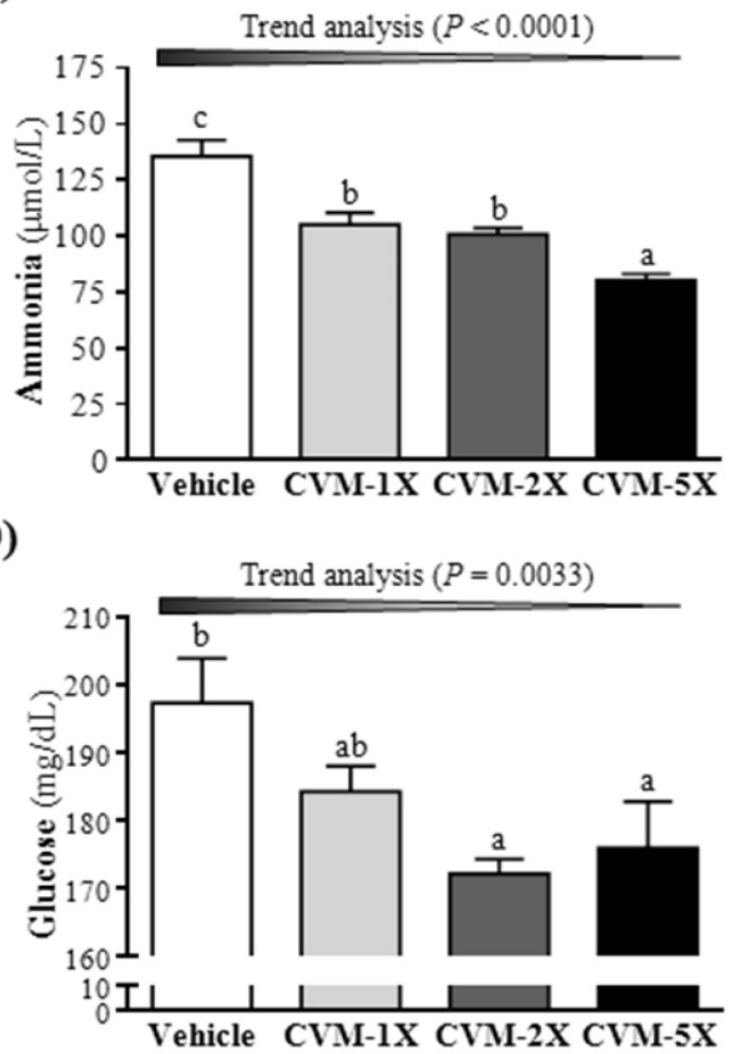

Figure 2. Effect of 4-week CVM on (A) blood lactate, (B) blood ammonia, (C) creatine kinase (CK) and (D) glucose following a 15 min swim test. Mice were pretreated with vehicle, CVM-1X, CVM-2X and CVM-5X for 28 days. Vehicle; vehicle control, CVM-1X; $615 \mathrm{mg} / \mathrm{kg} /$ day of CVM, CVM-2X; $1230 \mathrm{mg} / \mathrm{kg} / \mathrm{day}$ of CVM, CVM-5X; $3075 \mathrm{mg} / \mathrm{kg} /$ day of CVM. Data are mean \pm SEM ( $n=8$ mice $/ g r o u p)$. Different letters indicated significant difference at $p<0.05$ by one-way ANOVA. 
As shown in Table 2, the serum glucose level of CVM-1X (187 $\pm 5 \mathrm{mg} / \mathrm{dL})$, CVM-2X $(177 \pm 6 \mathrm{mg} / \mathrm{dL})$ and CVM-5X $(173 \pm 5 \mathrm{mg} / \mathrm{dL})$ groups was decreased compared to the vehicle control group $(193 \pm 8$ $\mathrm{mg} / \mathrm{dL}$ ). In this study, CVM treatment reduced the serum glucose levels both at rest and post-exercise. Therefore, we suggested that CVM may promote the glucose utilization to peripheral tissues and has a glucose lowering action.

Table 2. Effect of 4-week CVM on biochemical assessments of energy metabolism in mice

\begin{tabular}{llllll}
\hline & Vehicle & CVM-1X & CVM-2X & CVM-5X & Trend analysis \\
\hline CK (U/L) & $132 \pm 17^{\mathrm{b}}$ & $90 \pm 9 \mathrm{a}$ & $99 \pm 10^{\mathrm{a}}$ & $86 \pm 7^{\mathrm{a}}$ & 0.0353 \\
Glucose (mg/dL) & $193 \pm 8^{\mathrm{b}}$ & $187 \pm 5^{\mathrm{ab}}$ & $177 \pm 6^{\mathrm{ab}}$ & $173 \pm 5^{\mathrm{a}}$ & 0.0024 \\
LDH (U/L) & $297 \pm 16^{\mathrm{ab}}$ & $302 \pm 12^{\mathrm{ab}}$ & $325 \pm 13^{\mathrm{b}}$ & $270 \pm 13^{\mathrm{a}}$ & 0.3523 \\
T-Chol (mg/dL) & $156 \pm 5^{\mathrm{a}}$ & $147 \pm 6^{\mathrm{a}}$ & $143 \pm 4^{\mathrm{a}}$ & $143 \pm 5^{\mathrm{a}}$ & 0.0894 \\
TG (mg/dL) & $103 \pm 9^{\mathrm{b}}$ & $87 \pm 9 \mathrm{~b}$ & $51 \pm 6^{\mathrm{a}}$ & $51 \pm 4^{\mathrm{a}}$ & $<0.0001$ \\
\hline Mice were pretreated with vehicle, CVM-1X, CVM-2X and CVM-5X for 28 days. \\
Vehicle; vehicle control, CVM-1X; 615 mg/kg/day of CVM, CVM-2X; 1230 \\
mg/kg/day of CVM, CVM-5X; 3075 mg/kg/day of CVM. Data are mean $\pm \mathrm{SEM}(n=$ \\
8 mice/group). Different letters indicated significant difference at p<0.05 by \\
one-way ANOVA. A statistically significant dose-trend was p<0.05 by the SPSS \\
19.0.
\end{tabular}

After treatment with CVM or vehicle to mice for 28 days, serum LDH level was notably lower with CVM-5X $(270 \pm 13 \mathrm{U} / \mathrm{L})$ than the vehicle treatment $(297 \pm 16 \mathrm{U} / \mathrm{L})$. The TG level of the CVM-1X mice was $87 \pm 9 \mathrm{mg} / \mathrm{dL}(15 \%$ lower than that of the vehicle control group); the TG level of the CVM-2X mice was $51 \pm 6 \mathrm{mg} / \mathrm{dL}$ ( $51 \%$ lower than that of the vehicle control group); the TG level of the CVM-5X mice was $51 \pm 4 \mathrm{mg} / \mathrm{dL}(51 \%$ lower than that of the vehicle control group). There was a significant dose-dependent effect on the serum TG level $(p<0.0001)$. Therefore, the supplementation with CVM could reduce the risk of atherosclerosis, heart disease and stroke.

\section{Effect of 4-week CVM on biochemical assessments of kidney function and liver function}

The biochemical data of liver function, including ALB, ALP, ALT, AST and TP, from the serum in the vehicle control, CVM-1X, CVM-2X and CVM-5X groups were shown in Table 3 . The vehicle control group exhibited a higher ALP $(350 \pm 13 \mathrm{U} / \mathrm{L})$ and ALT (U/L) levels compared with the CVM groups. But there were no significant differences in ALB, AST and $\mathrm{TP}$ of the mice in CVM groups, in comparison with the vehicle control group. However, after treatment with CVM or vehicle to mice for 28 days, serum ALP level was notably lower with CVM-5X $(291 \pm 17$ U/L) than the vehicle treatment $(350 \pm 13 \mathrm{U} / \mathrm{L})(\mathrm{p}<0.05)$. The ALT level of the CVM-5X mice was $42 \pm 1 \mathrm{U} / \mathrm{L}(18 \%$ lower than that of the vehicle control group) $(p<0.05)$. Thus, the supplementation with CVM could protect liver by decreasing the levels of ALP and ALT

On the other hand, there were no significant differences in kidney function, including BUN, CREA and UA, of the mice in CVM groups, in comparison with the vehicle control group (Table 3). Thus, the supplementation with CVM had no damage for kidney.

Table 3. E Effect of 4-week CVM on biochemical assessments of liver and kidney function in mice

\begin{tabular}{lllll}
\hline & Vehicle & CVM-1X & CVM-2X & CVM-5X \\
\hline ALB (g/dL) & $3.4 \pm 0.0^{\mathrm{ab}}$ & $3.3 \pm 0.0^{\mathrm{a}}$ & $3.4 \pm 0.0^{\mathrm{b}}$ & $3.4 \pm 0.0^{\mathrm{b}}$ \\
ALP (U/L) & $350 \pm 13^{\mathrm{b}}$ & $299 \pm 11^{\mathrm{a}}$ & $346 \pm 21^{\mathrm{b}}$ & $291 \pm 17^{\mathrm{a}}$ \\
ALT (U/L) & $51 \pm 4^{\mathrm{b}}$ & $48 \pm 2^{\mathrm{ab}}$ & $49 \pm 3^{\mathrm{ab}}$ & $42 \pm 1^{\mathrm{a}}$ \\
AST (U/L) & $65 \pm 3^{\mathrm{a}}$ & $61 \pm 2^{\mathrm{a}}$ & $67 \pm 4^{\mathrm{a}}$ & $59 \pm 2^{\mathrm{a}}$ \\
TP (g/dL) & $5.6 \pm 0.0^{\mathrm{ab}}$ & $5.5 \pm 0.1^{\mathrm{a}}$ & $5.7 \pm 0.1^{\mathrm{bc}}$ & $5.7 \pm 0.1^{\mathrm{c}}$ \\
BUN (mg/dL) & $25.9 \pm 0.5^{\mathrm{a}}$ & $26.8 \pm 0.6^{\mathrm{a}}$ & $25.7 \pm 0.5^{\mathrm{a}}$ & $26.5 \pm 0.5^{\mathrm{a}}$ \\
CREA (mg/dL) & $0.25 \pm 0.01^{\mathrm{ab}}$ & $0.25 \pm 0.00^{\mathrm{a}}$ & $0.27 \pm 0.00^{\mathrm{b}}$ & $0.27 \pm 0.01^{\mathrm{b}}$ \\
UA (mg/dL) & $1.00 \pm 0.08^{\mathrm{a}}$ & $1.11 \pm 0.06^{\mathrm{a}}$ & $1.04 \pm 0.07^{\mathrm{a}}$ & $1.08 \pm 0.04^{\mathrm{a}}$ \\
\hline
\end{tabular}

Mice were pretreated with vehicle, CVM-1X, CVM-2X and CVM-5X for 28 days. Vehicle; vehicle control, CVM-1X; $615 \mathrm{mg} / \mathrm{kg} /$ day of CVM, CVM-2X; 1230 $\mathrm{mg} / \mathrm{kg} /$ day of CVM, CVM-5X; $3075 \mathrm{mg} / \mathrm{kg} /$ day of CVM. Data are mean \pm SEM $(n=$ 8 mice/group). Different letters indicated significant difference at $\mathrm{p}<0.05$ by one-way ANOVA.

\section{Effect of 4-week CVM on pathological histology of liver, muscle, heat, kidney and lung tissues}

The pathological histology of the major organs, including the liver, muscle, heat, kidney and lung tissues were shown in Fig. 3. The groups did not differ in histological observations of liver, muscle, heat, kidney and lung tissues of the mice in CVM groups, in comparison with the vehicle control group.

\section{Conclusions}

In this study, CVM increased grip strength that improved physical fatigue and exercise performance in mice. In addition, we found CVM has anti-fatigue activity by decreasing serum lactate, ammonia and $\mathrm{CK}$ and levels concentration at post-exercise, thereby elevating exercise performance in mice. Furthermore, CVM treatment reduced the glucose levels both at rest and post-exercise. Thus, we suggested that CVM may promote the glucose utilization to peripheral tissues and has a glucose lowering action. The present results suggested that gavage treatment with CVM once a day for 28 consecutive days shows an anti-fatigue effect. In this study, 615, 1230 and $3075 \mathrm{mg} / \mathrm{kg}$ BW of mice are equivalent to $68.3,136.5$ and $341.3 \mathrm{mg} / \mathrm{kg}$ of human, respectively. Even when human administered at several times the therapeutically effective dosage and over extended periods, CVM is still no toxic [28]. At 100-fold of the normal clinical dose of CVM, it has not induced any acute and chronic toxicity in animals [28]. Therefore, these results showed that CVM had great potential in anti-fatigue activity. 


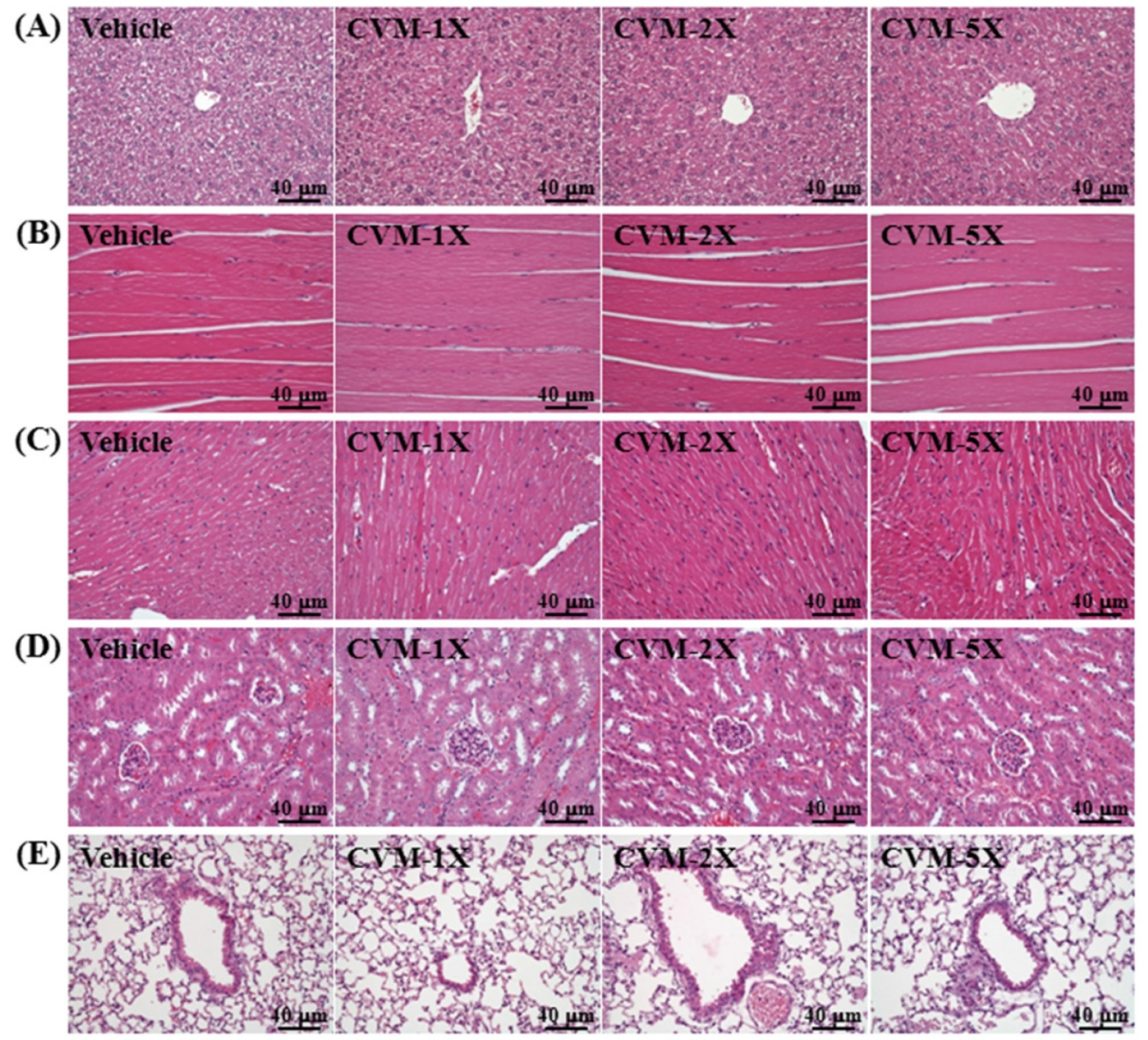

Figure 3. Effect of 4-week CVM on pathological histology of liver, muscle, heat, kidney and lung tissues. Mice were pretreated with vehicle, CVM-1X, CVM-2X and CVM-5X for 28 days. Vehicle; vehicle control, CVM-1X; $615 \mathrm{mg} / \mathrm{kg} /$ day of CVM, CVM-2X; $1230 \mathrm{mg} / \mathrm{kg} / \mathrm{day}$ of CVM, CVM-5X; $3075 \mathrm{mg} / \mathrm{kg} / \mathrm{day}$ of CVM.

\section{Acknowledgments}

This research was supported by the Ministry of Science and Technology of Taiwan (grant no. MOST-104-2811-B-179-001 to Chi-Chang Huang) and an institutional grant to Chun-Sheng Ho (Lo-Hsu Foundation, Inc., Lotung Poh-Ai Hospital). The authors are grateful to Drs. Chien-Chao Chiu, Hsiao-Li Chuang and Chin-Shan Ho for technical assistance in animal experiments.

\section{Authors' contributions}

Chun-Sheng Ho, Chi-Chang Huang and Jyh-Horng $\mathrm{Wu}$ designed the experiments. Wen-Ching Huang, Wing-Ki Leung and Chi-Chang Huang carried out the laboratory experiments. Chun-Sheng Ho, Yu-Tang Tung, Woon-Man Kung, Chi-Chang Huang and Jyh-Horng $\mathrm{Wu}$ analyzed the data, interpreted the results, prepared figures, and wrote the manuscript. Chun-Sheng Ho, Yu-Tang Tung, Chi-Chang Huang and Jyh-Horng $\mathrm{Wu}$ revised the manuscript. Chun-Sheng Ho, Chi-Chang Huang and Jyh-Horng $\mathrm{Wu}$ contributed reagents, materials and analysis platforms.

\section{Competing Interests}

The authors have declared that no competing interest exists.

\section{References}

1. Tharakan B, Dhanasekaran M, Brown-Borg HM, Manyam BV. Trichopus zeylanicus combats fatigue without amphetamine-mimetic activity. Phytotherapy Research. 2006; 20: 165-168.

2. Uthayathas S, Karuppagounder SS, Tamer SI, Parameshwaran K, Degim T, Suppiramaniam $\mathrm{V}$, et al. Evaluation of neuroprotective and anti-fatigue effects of sildenafil. Life Sciences. 2007; 81: 988-992.

3. Huang CC, Hsu MC, Huang WC, Yang HR, Hou CC. Triterpenoid-rich extract from Antrodia camphorata improves physical fatigue and exercise performance in mice. Evidence-Based Complementary and Alternative Medicine. 2012; 2012: 364741.

4. Jong SC, Yang XT. PSP-a powerful biological response modifier from the mushroom Coriolus versicolor. In: Yang QY. International Symposium on 
Traditional Chinese Medicine and Cancer: Development and Clinical Validation-Advances research in PSP. 1999.

5. Li XY. Advances in immunomodulating studies of PSP. In: Yang QY. Advance research in PSP. Hong Kong: The Hong Kong association for health care Ltd. 1999, 39-46.

6. Cui J, Chisti Y. Polysaccharopeptides of Coriolus versicolor: physiological activity, uses, and production. Biotechnology Advances. 2003; 21: 109-122.

7. Zhang HL, Li J, Li G, Wang DM, Zhu LP, Yang DP. Structural characterization and anti-fatigue activity of polysaccharides from the roots of Morinda officinalis. International Journal of Biological Macromolecules. 2009; 44: 257-261.

8. Wang J, Li S, Fan Y, Chen Y, Liu D, Cheng H, et al. Anti-fatigue activity of the water-soluble polysaccharides isolated from Panax ginseng C. A. Meyer. Journal of Ethnopharmacology. 2010; 130: 421-423.

9. Li X, Zhang $\mathrm{H}, \mathrm{Xu} \mathrm{H}$. Analysis of chemical components of shiitake polysaccharides and its anti-fatigue effect under vibration. International Journal of Biological Macromolecules. 2009; 45: 377-380.

10. Zheng SQ, Jiang F, Gao HY, Zheng JG. Preliminary observations on the antifatigue effects of longan (Dimocarpus longan Lour.) seed polysaccharides. Phytotherapy Research. 2010; 24: 622-624.

11. Tang W, Gao Y, Chen G, Gao H, Dai X, Ye J, et al. A randomized, double-blind and placebo-controlled study of a Ganoderma lucidum polysaccharide extract in neurasthenia. Journal of Medicinal Food. 2005; 8: 53-58.

12. Tan $\mathrm{W}$, Yu KQ, Liu YY, Ouyang MZ, Yan MH, Luo R, et al. Anti-fatigue activity of polysaccharides extract from Radix Rehmanniae Preparata. International Journal of Biological Macromolecules. 2012; 50: 59-62.

13. Wang SY, Huang WC, Liu CC, Wang MF, Ho CS, Huang WP, et al. Pumpkin (Cucurbita moschata) fruit extract improves physical fatigue and exercise performance in mice. Molecules. 2012; 17: 11864-11876.

14. Wu RE, Huang WC, Liao CC, Chang YK, Kan NW, Huang CC. Resveratrol protects against physical fatigue and improves exercise performance in mice. Molecules. 2013; 18: 4689-4702.

15. Chen WC, Huang WC, Chiu CC, Chang YK, Huang CC. Whey protein improves exercise performance and biochemical profiles in trained mice. Medicine \& Science in Sports \& Exercise. 2014; 46: 1517-1524.

16. Belluardo N, Westerblad H, Mudó G, Casabona A, Bruton J, Caniglia G, et al. Neuromuscular junction disassembly and muscle fatigue in mice lacking neurotrophin-4. Molecular and Cellular Neuroscience. 2001; 18: 56-67.

17. Zhang $Y$, Yao XB, Bao BL, Zhang Y. Anti-fatigue activity of a triterpenoid-rich extract from Chinese bamboo shavings (Caulis bamfusae in taeniam). Phytotherapy Research. 2006; 20: 872-876.

18. Tanaka M, Nakamura F, Mizokawa S, Matsumura A, Nozaki S, Watanabe Y. Establishment and assessment of a rat model of fatigue. Neuroscience Letters. 2003; 352: 159-162.

19. $\mathrm{Ng}$ TB A review of research on the protein-bound polysaccharide (polysaccharopeptide, PSP) from the mushroom Coriolus versicolor (Basidiomycetes: Polyporaceae). General Pharmacology. 1998; 30: 1-4.

20. Kim KM, $\mathrm{Y}_{\mathrm{u}} \mathrm{KW}$, Kang $\mathrm{DH}$, Koh JH, Hong BS, Suh HJ. Anti-stress and anti-fatigue effects of fermented rice bran. Phytotherapy Research. 2002; 16: $700-702$.

21. Koo HN, Lee JK, Hong SH, Kim HM. Herbkines increases physical stamina in mice. Biological and Pharmaceutical Bulletin. 2004; 27: 117-119.

22. Yu B, Lu ZX, Bie XM, Lu FX, Huang XQ. Scavenging and anti-fatigue activity of fermented defatted soybean peptides. European Food Research and Technology. 2008; 226: 415-421.

23. Li M, Donglian C, Huaixing L, Bende T, Lihua S, Ying W. Anti-fatigue effects of salidroside in mice. Journal of Medical Colleges of PLA. 2008; 23: 88-93.

24. Jin HM, Wei P. Anti-fatigue properties of tartary buckwheat extracts in mice. International Journal of Molecular Sciences. 2011: 12: 4770-4780.

25. Tashiro S. Studies on alkaligenesis in tissues: I. Ammonia production in the nerve fiber during excitation. American Journal of Physiology. 1922; 60: 519-543.

26. Prado ES, de Rezende Neto JM, de Almeida RD, Dória de Melo MG, Cameron LC. Keto analogue and amino acid supplementation affects the ammonaemia response during exercise under ketogenic conditions. British Journal of Nutrition. 2011; 105: 1729-1733.

27. Warren GL, Ingalls $\mathrm{CP}$, Lowe DA, Armstrong RB. Excitation-contraction uncoupling: major role in contraction-induced muscle injury. Exercise and Sport Sciences Reviews. 2001; 29: 82-87.

28. Cui J, Chisti Y. Polysaccharopeptides of Coriolus versicolor: physiological activity, uses, and production. Biotechnology Advances. 2003; 21: 109-122. 